\title{
Syntrophomonas curvata sp. nov., an anaerobe that degrades fatty acids in co-culture with methanogens
}

\author{
Chunyang Zhang, Xiaoli Liu and Xiuzhu Dong \\ State Key Laboratory of Microbial Resources, Institute of Microbiology, Chinese Academy of \\ Sciences, Beijing 100080, P.R. China
}

Correspondence

Xiuzhu Dong

dongxz@sun.im.ac.cn

\begin{abstract}
A strict anaerobe (strain GB8-1 $1^{\top}$ ) that degraded straight-chain fatty acids with $\mathrm{C}_{4}-\mathrm{C}_{18}$ in syntrophic association with methanogens was isolated from an up-flow anaerobic sludge blanket reactor treating beer wastewater. Strain GB8-1 ${ }^{\top}$ degraded 1 mol butyrate into about 2 mol acetate and $1 \mathrm{~mol}$ (presumably) $\mathrm{H}_{2}$ in co-culture with a methanogen. Neither branched-chain fatty acids nor benzoate could be degraded. Strain GB8-1 ${ }^{\top}$ could grow on crotonate in pure culture and converted $1 \mathrm{~mol}$ crotonate to $0.5 \mathrm{~mol}$ butyrate and 1 mol acetate. Generation time was about $11 \mathrm{~h}$ when grown on crotonate at $37^{\circ} \mathrm{C}$. Fumarate, sulfate, thiosulfate, sulfur and nitrate could not serve as electron acceptors for strain GB8-1 ${ }^{\top}$ to degrade butyrate. Cells of strain GB8-1 ${ }^{\top}$ were curved rods with Gram-negative cell walls; no spores were observed. The DNA G + C content was $46 \cdot 6$ mol\%. Phylogenetic analysis based on 16S rRNA gene sequences revealed that strain GB8 $-1^{\top}$ was related most closely to the fatty acid-oxidizing, syntrophic bacterium Syntrophomonas sapovorans DSM $3441^{\top}$; however, the relationship was not very close ( $95.4 \%$ sequence similarity). Some phenotypic features also differentiated strain GB8-1 ${ }^{\top}$ from Syntrophomonas sapovorans DSM $3441^{\top}$. Therefore, a novel species, Syntrophomonas curvata sp. nov., is proposed. The type strain is GB8 $-1^{\top}\left(=\right.$ CGMCC $1.5010^{\top}=$ DSM $\left.15682^{\top}\right)$.
\end{abstract}

In ecosystems that lack light and exogenous electron acceptors other than $\mathrm{CO}_{2}$, mineralization of complex organic matter is performed by the cooperation of three major metabolic groups of micro-organisms: hydrolytic and fermenting bacteria; syntrophic, acetogenic bacteria; and methanogens. Butyric acid is an important metabolic intermediate during this mineralization. Due to the unfavourable energetics of the reaction under standard thermodynamic conditions, it can only be degraded by the synergetic reaction of syntrophic, acetogenic bacteria and hydrogen-scavenging microbes, such as methanogens (Schink, 1997).

To date, seven species and/or subspecies have been described to degrade butyric acid, as well as some long-chain fatty acids (up to $\mathrm{C}_{18}$ ), syntrophically. Both physiological

Published online ahead of print on 9 January 2004 as DOI 10.1099/ ijs.0.02903-0.

Abbreviations: FAME, fatty acid methyl ester; UASB, up-flow anaerobic sludge blanket.

The GenBank/EMBL/DDBJ accession number for the 16S rRNA gene sequence of Syntrophomonas curvata strain GB8-1 ${ }^{\top}$ is AY290767.

Transmission electron micrographs of strain $\mathrm{GB} 8-1^{\top}$ are available as supplementary material in IJSEM Online. and genetic characterization suggested that six of them belonged to the family Syntrophomonadaceae (McInerney, 1992; Zhao et al., 1993), within the phylum of low-G +C, Gram-positive bacteria. They are Thermosyntropha lipolytica DSM $11003^{\mathrm{T}}$ (Svetlitshnyi et al., 1996), Syntrophothermus lipocalidus DSM $12680^{\mathrm{T}}$ (Sekiguchi et al., 2000), Syntrophospora bryantii DSM $3014^{\mathrm{T}}$ (Stieb \& Schink, 1985; Zhao et al., 1990), Syntrophomonas wolfei subsp. wolfei DSM $2245^{\mathrm{T}}$ (McInerney et al., 1979, 1981; Beaty \& McInerney, 1987), Syntrophomonas wolfei subsp. saponavida DSM $4212^{\mathrm{T}}$ (Lorowitz et al., 1989) and Syntrophomonas sapovorans DSM $3441^{\mathrm{T}}$ (Roy et al., 1986). Syntrophus aciditrophicus ATCC $700169^{\mathrm{T}}$, a bacterium that syntrophically degrades both fatty acids $\left(\mathrm{C}_{4}-\mathrm{C}_{18}\right)$ and benzoate, was affiliated to the $\delta$-Proteobacteria and clustered with the syntrophic bacteria that oxidize propionate or benzoate (Jackson et al., 1999). In the present study, we isolated a new anaerobe, strain GB8- $1^{\mathrm{T}}$, that syntrophically degraded $\mathrm{C}_{4}-\mathrm{C}_{18}$ straight-chain fatty acids in co-culture with a hydrogenotrophic microbe. Phylogenetic analysis indicated that strain GB8-1 $1^{\mathrm{T}}$ was a member of the genus Syntrophomonas; however, it was not related closely to either of the described species in this genus. Moreover, it could be distinguished from the other species by cell shape and substrate range.

Strain GB8-1 ${ }^{\mathrm{T}}$ was isolated from granular sludge that was 
sampled from a lab-scale, mesophilic, up-flow anaerobic sludge blanket (UASB) reactor treating beer wastewater in Tsinghua University, Beijing, China. Methanobacterium formicicum DSM $1535^{\mathrm{T}}$ was kindly provided by Dr Alfons Stams in the Department of Microbiology, Wageningen University, the Netherlands, and Syntrophomonas sapovorans DSM $3441^{\mathrm{T}}$ was purchased from the DSMZ (Braunschweig, Germany).

The pre-reduced basal medium used in this study was prepared as described by McInerney et al. (1979), except that the growth-stimulating factors used were $0.05 \%(\mathrm{w} / \mathrm{v})$ yeast extract and $0.05 \%(\mathrm{w} / \mathrm{v})$ tryptone, instead of $5.0 \%$ $(\mathrm{v} / \mathrm{v})$ rumen fluid. The gas phase was $\mathrm{N}_{2} / \mathrm{CO}_{2} \quad(80: 20$; $\left.1 \cdot 01 \times 10^{5} \mathrm{~Pa}\right)$, except that it comprised $\mathrm{H}_{2} / \mathrm{CO}_{2}(80: 20$; $1 \cdot 25 \times 10^{5} \mathrm{~Pa}$ ) for cultivating M. formicicum DSM $1535^{\mathrm{T}}$. All inoculations and transfers were done with syringes and needles and all cultures were incubated at $37^{\circ} \mathrm{C}$ in the dark unless indicated. Purity of strain GB8- $1^{\mathrm{T}}$ in co-culture and pure culture was examined periodically by monitoring cell morphology under a normal bright-field microscope and clones on solid media, as well as monitoring lack of growth in a rich medium like peptone/yeast extract/glucose (PYG) medium.

To test the substrate range of strain GB8- $1^{\mathrm{T}}$ in co-culture with a methanogen, the following organic acids were each used as the sole substrate: acetate, propionate, isobutyrate, butyrate, isovalerate and valerate $(20 \mathrm{mM}$ each); caproate, heptanoate, caprylate and benzoate (10 $\mathrm{mM}$ each); caprate, undecanoate, laurate, myristate, pentadecanoate, palmitate, margarate, stearate, oleate and linoleate $(5 \mathrm{mM}$ each, with equimolar $\mathrm{CaCl}_{2}$ ). After inoculation, cultures were incubated for up to 60 days. Meanwhile, acetate, propionate and methane production and substrate degradation were measured. Cell growth was monitored by measurement of the $\mathrm{OD}_{600}$ of the culture. Fatty acids and $\mathrm{CH}_{4}$ were detected by GC (GC-14B, Shimadzu) as described by Touzel \& Albagnac (1983); $\mathrm{N}_{2}$ acted as the carrier gas. Column temperatures were 50 and $220^{\circ} \mathrm{C}$ for the $\mathrm{CH}_{4}$ and shortchain fatty acid assays, respectively. Fatty acids longer than $\mathrm{C}_{7}$ were esterified into fatty acid methyl esters (FAMEs) before being measured and column temperatures were 200, 220 and $240^{\circ} \mathrm{C}$ for $\mathrm{C}_{8}-\mathrm{C}_{13}, \mathrm{C}_{14}-\mathrm{C}_{17}$ and $\mathrm{C}_{18}$ fatty acids, respectively. Benzoate was measured by HPLC (series 1050, Hewlett Packard) as described by Jackson et al. (1999). The molar growth yield of strain GB8-1 ${ }^{\mathrm{T}}$ in pure culture on crotonate was determined according to the method of Jackson et al. (1999).

In order to determine optimum growth conditions for strain GB8- $1^{\mathrm{T}}$ in co-culture and pure culture, basal medium with $20 \mathrm{mM}$ butyrate and crotonate, respectively, was used. The $\mathrm{pH}$ of the media was adjusted to $5 \cdot 5-9 \cdot 5$ by using $1 \mathrm{M}$ $\mathrm{HCl}$ or $1 \mathrm{M} \mathrm{NaOH}$. To determine the growth temperature profile, cultures were incubated at $15-55^{\circ} \mathrm{C}(\mathrm{pH} 7 \cdot 5)$ in a water bath with a temperature controller. To determine $\mathrm{NaCl}$ tolerance, $0-1000 \mathrm{mM} \mathrm{NaCl}$ was added to the media. After cultivation for up to 60 days, growth was determined by measurement of the $\mathrm{OD}_{600}$ of the culture and substrate degradation. All determinations were performed in duplicate with $10 \%$ inoculum.

Exponential-phase cells of strain GB8- ${ }^{\mathrm{T}}$ were used for morphology examination with a transmission electron microscope (H-600A, Hitachi). Before observation, negative staining was performed with uranyl acetate. Ultrathin sections were stained with uranyl acetate and lead citrate, according to Reynolds (1963).

Diamino acids of the cell wall were assayed by TLC on a cellulose plate; the solvent system of Rhuland et al. (1955) was used. Whole-cell fatty acids were analysed as FAMEs with the MIDI Microbial Identification system.

Genomic DNA was extracted from cells of strain GB8-1 ${ }^{\mathrm{T}}$ grown on crotonate, as described by Marmur (1961). The DNA $G+C$ content was determined by using the thermal denaturation method (Marmur \& Doty, 1962) with a DU 800 spectrophotometer (Beckman). DNA from Escherichia coli $\mathrm{K}-12$ was used as reference for determination of the thermal-melting profile $\left(T_{\mathrm{m}}\right)$.

The 16S rRNA gene of strain GB8- $1^{\mathrm{T}}$ was amplified by PCR and sequenced by using methods described by Weisburg et al. (1991). The 16S rRNA gene sequences of strain GB8- $1^{\mathrm{T}}$ and reference strains in GenBank were aligned by using the DNAMAN program (version 4.0; Lynnon Biosoft). A phylogenetic tree was constructed with the neighbourjoining method and the topology of the phylogenetic tree was evaluated by bootstrap analysis of the sequence data with the DNAMAN program.

Granular sludge was inoculated into a medium with $20 \mathrm{mM}$ butyrate, in order to enrich anaerobic, butyrate-degrading consortia. After many roll-tube isolation steps (Hungate, $1969)$ in the butyrate medium, in which $5 \%(\mathrm{v} / \mathrm{v})$ culture of M. formicicum DSM $1535^{\mathrm{T}}$ and $5 \%(\mathrm{v} / \mathrm{v})$ dilution of the enrichment culture were inoculated, a biculture that produced methane on butyrate, but not on PYG medium, was obtained. This biculture formed brownish colonies of $0.5-1.0 \mathrm{~mm}$ diameter in roll tubes and with green fluorescence under light at $420 \mathrm{~nm}$. Only two kinds of cell shape were observed in the biculture: one was a straight, M. formicicum-like rod and the other was a slightly curved rod. The biculture was purified further on medium with $20 \mathrm{mM}$ crotonate as the sole substrate (instead of butyrate) and $10 \mathrm{mM}$ 2-bromoethanesulfonic acid to inhibit the methanogen; a monoculture, designated strain GB8-1 ${ }^{\mathrm{T}}$, was obtained. Strain GB8 $-1^{\mathrm{T}}$ hardly grew on solid medium in pure culture; tiny white colonies of $0 \cdot 1-0 \cdot 2 \mathrm{~mm}$ diameter were formed. Strain GB8- $1^{\mathrm{T}}$ neither grew on butyrate alone nor produced $\mathrm{CH}_{4}$, whereas it degraded butyrate in an artificially constructed co-culture with $M$. formicicum DSM $1535^{\mathrm{T}}$.

Cells of strain GB8-1 $1^{\mathrm{T}}$ were slightly curved rods with round to acute ends that were $0 \cdot 5-0 \cdot 7 \mu \mathrm{m}$ in width and 
$2 \cdot 3-4 \cdot 0 \mu \mathrm{m}$ in length and occurred singly, in pairs or in helical filaments. Negative staining showed the presence of one to three flagella inserted in one or both poles or subpoles (see Supplementary Figure, available in IJSEM Online). Spores were not observed. Although the Gram reaction of the cell wall was variable, a Gram-negative structure was revealed by ultrathin section (see Supplementary Figure, available in IJSEM Online).

Strain GB8-1 ${ }^{\mathrm{T}}$ could degrade 1 mol butyrate into about 2 mol acetate and 1 mol (presumably) $\mathrm{H}_{2}$, which was consumed by M. formicicum DSM $1535^{\mathrm{T}}$ in the co-culture within 3 weeks. Electron and carbon recoveries of butyrate degradation were $102 \cdot 19 \pm 2 \cdot 23$ and $96 \cdot 57 \pm 2 \cdot 60 \%$, respectively. Straight-chain fatty acids with $4-18$ carbons could be degraded by the co-culture (Table 1); however, neither branched-chain fatty acids, such as isobutyrate and isovalerate, nor benzoate were degraded. Among the substrates used, fatty acids with an even number of carbons were converted into acetate and $\mathrm{H}_{2}$, whereas those with an odd number of carbons were converted into propionate, acetate and $\mathrm{H}_{2}$, implying that $\beta$-oxidation of fatty acids was performed by the co-culture. None of the following substances could be used by strain GB8- $1^{\mathrm{T}}$ as a potential electron acceptor for butyrate degradation: sodium sulfate $(20 \mathrm{mM})$, sodium thiosulfate $(20 \mathrm{mM})$, sulfur $(20 \mathrm{mM})$, sodium nitrate $(20 \mathrm{mM})$ or sodium fumarate $(20 \mathrm{mM})$. These results indicate the affiliation of strain GB8 $-1^{\mathrm{T}}$ to the syntrophic acetogen group.

Crotonate was the only compound tested that supported growth of strain GB8-1 $1^{\mathrm{T}}$ in pure culture; $1 \mathrm{~mol}$ crotonate was disproportioned into about $0.5 \mathrm{~mol}$ butyrate and $1 \mathrm{~mol}$ acetate in 7 days (with electron and carbon recoveries of $93 \cdot 13 \pm 1.98$ and $94 \cdot 19 \pm 1.97 \%$, respectively). Doubling time of strain GB8-1 ${ }^{\mathrm{T}}$ was $11 \mathrm{~h}$ when grown on $20 \mathrm{mM}$ crotonate at $37^{\circ} \mathrm{C}$. The molar growth yield of strain GB8- $1^{\mathrm{T}}$ on crotonate was $4 \cdot 0-4 \cdot 8 \mathrm{~g}$ dry wt $\mathrm{mol}^{-1}$. Growth and acid formation were not observed on the following substrates: yeast extract $(0.5 \%)$, tryptone $(1 \%)$, glucose $(20 \mathrm{mM})$, ribose $(20 \mathrm{mM})$, xylose $(20 \mathrm{mM})$, pyruvate $(20 \mathrm{mM})$ and fumarate $(20 \mathrm{mM})$.

Temperature ranges for the co-culture on butyrate and pure culture on crotonate were both $20-42{ }^{\circ} \mathrm{C}$, with optimal growth at $35-37^{\circ} \mathrm{C}$; the $\mathrm{pH}$ range for both types of culture

Table 1. Characteristics of strain GB8-1 $1^{\top}$ and other mesophilic, syntrophic bacteria in the family Syntrophomonadaceae

Species: 1, Syntrophospora bryantii DSM $3014^{\mathrm{T}} ; 2$, Syntrophomonas wolfei subsp. wolfei DSM $2245^{\mathrm{T}}$; 3 , Syntrophomonas wolfei subsp. saponavida DSM 4212 ${ }^{\mathrm{T}}$; 4, Syntrophomonas sapovorans DSM $3441^{\mathrm{T}}$; 5, Syntrophomonas curvata GB8-1 ${ }^{\mathrm{T}}$. Data are from Stieb \& Schink (1985), Zhao et al. (1990), McInerney et al. (1979, 1981), Beaty \& McInerney (1987), Lorowitz et al. (1989), Roy et al. (1986) and this study. All species were positive for production of caprylate from butyrate. Abbreviation: ND, not determined.

\begin{tabular}{|c|c|c|c|c|c|}
\hline Characteristic & 1 & 2 & 3 & 4 & 5 \\
\hline Cell width $(\mu \mathrm{m})$ & $0 \cdot 4$ & $0 \cdot 5-1 \cdot 0$ & $0 \cdot 4-0 \cdot 6$ & $0 \cdot 5$ & $0 \cdot 5-0 \cdot 7$ \\
\hline Cell length $(\mu \mathrm{m})$ & $3 \cdot 0-6 \cdot 0$ & $2 \cdot 0-7 \cdot 0$ & $2 \cdot 0-4 \cdot 0$ & $2 \cdot 5$ & $2 \cdot 3-4 \cdot 0$ \\
\hline Motility & - & + & + & + & + \\
\hline DNA G + C content $(\mathrm{mol} \%)$ & $37 \cdot 6$ & ND & ND & ND & $46 \cdot 6$ \\
\hline Spore formation & + & - & - & - & - \\
\hline \multicolumn{6}{|l|}{ Substrate utilization in pure culture: } \\
\hline Crotonate & + & + & + & - & + \\
\hline \multicolumn{6}{|c|}{ Substrate utilization in co-culture with methanogens: } \\
\hline Acetate & ND & - & ND & - & - \\
\hline Myristate & - & ND & + & + & + \\
\hline Palmitate & - & - & + & + & + \\
\hline Stearate & - & - & + & + & + \\
\hline Oleate & $\mathrm{ND}$ & - & - & + & + \\
\hline Linoleate & $\mathrm{ND}$ & ND & - & + & - \\
\hline Isobutyrate & - & - & - & - & - \\
\hline Isovarelate & ND & - & - & - & - \\
\hline Triacylglycerides & ND & ND & - & - & $\mathrm{ND}$ \\
\hline
\end{tabular}


was $6 \cdot 3 \pm 8 \cdot 4$, with an optimal $\mathrm{pH}$ of $7 \cdot 5$; and the $\mathrm{NaCl}$ tolerance concentration ranges were both $0-100 \mathrm{mM}$ (better growth occurred below $50 \mathrm{mM} \mathrm{NaCl}$ ). No growth was observed when oxygen was present.

Peptidoglycan of strain GB8- ${ }^{\mathrm{T}}$ contained LL-diaminopimelic acid. The major fatty acids were as follows: $\mathrm{C}_{14: 0}(27 \cdot 82 \%)$, $\mathrm{C}_{15: 0}(19 \cdot 24 \%), \mathrm{C}_{14: 0} 3-\mathrm{OH}(10 \cdot 90 \%)$ and an unknown structure component, with quite a high percentage $(21 \cdot 44 \%)$, with an equivalent chain-length (ECL) of 14.503. The fatty acid profile was not similar to those of anaerobic bacteria in the MIDI database, as $\mathrm{C}_{16: 0}$ was one of the predominant fatty acids in many Clostridium spp. and Syntrophus aciditrophicus (Jackson et al., 1999; Broda et al., 2000); however, it occurred at a very low level $(2 \cdot 79 \%)$ in strain GB8- $1^{\mathrm{T}}$.

The genomic DNA G + C content of strain GB8- $1^{\mathrm{T}}$ was determined to be $46.6 \mathrm{~mol} \%$; this is different from those reported for the members of the Syntrophomonadaceae by 2.4-9 mol\% (Matthies et al., 2000; Sekiguchi et al., 2000).

A phylogenetic tree including strain GB8- $1^{\mathrm{T}}$ and other members of the family Syntrophomonadaceae was constructed (Fig. 1), based on a consensus length of 1395 bp of their $16 \mathrm{~S}$ rRNA genes. Sequence similarity showed that strain GB8- $1^{\mathrm{T}}$ was related most closely to Syntrophomonas sapovorans DSM $3441^{\mathrm{T}}(95 \cdot 4 \%$ similarity); similarities of $<93 \%$ were revealed with the other described species in the genus Syntrophomonas and other genera within the family Syntrophomonadaceae.

Although strain GB8-1 ${ }^{\mathrm{T}}$ was relatively closely related to Syntrophomonas sapovorans DSM $3441^{\mathrm{T}}$ phylogenetically, some phenotypic characters were different between the two strains. Syntrophomonas sapovorans DSM $3441^{\mathrm{T}}$ had

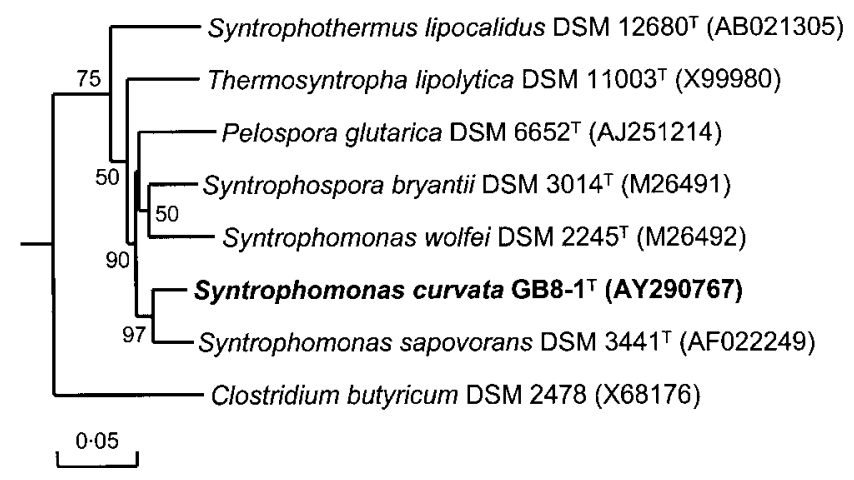

Fig. 1. Phylogenetic tree of strain $\mathrm{GB} 8-1^{\top}$ and related organisms, based on a $1395 \mathrm{bp}$ fragment of 16S rRNA gene sequences. The tree, rooted with Clostridium butyricum DSM 2478, was constructed by using the neighbour-joining method with bootstrap values based on 1000 replications. The number at each branch-point is the percentage supported by bootstrap; GenBank accession numbers of 16S rRNA gene sequences are given in parentheses. Bar, $5 \%$ sequence divergence. two to four lateral flagella inserted in the concave side of the cell, whereas strain GB8- $1^{\mathrm{T}}$ had one to three polar or subpolar flagella. Furthermore, Syntrophomonas sapovorans DSM $3441^{\mathrm{T}}$ did not grow on crotonate in pure culture, but degraded linoleate in co-culture (Table 1). Considering the phenotypic and phylogenetic distinctions, we propose strain GB8- $1^{\mathrm{T}}$ as the type strain of a novel species of the genus Syntrophomonas, Syntrophomonas curvata sp. nov.

\section{Description of Syntrophomonas curvata sp. nov.}

Syntrophomonas curvata (cur.va'ta. L. fem. adj. curvata curved).

Cells are Gram-negative, curved rods, $0 \cdot 5-0 \cdot 7 \times 2 \cdot 3-$ $4 \cdot 0 \mu \mathrm{m}$, non-spore-forming, with one to three polar or subpolar flagella. Straight-chain fatty acids with $\mathrm{C}_{4}-\mathrm{C}_{18}$ serve as substrates for strain GB8-1 $1^{\mathrm{T}}$ in co-culture with M. formicicum DSM $1535^{\mathrm{T}}$. Even-numbered fatty acids are degraded into acetate and presumably $\mathrm{H}_{2}$, whereas oddnumbered ones are degraded into propionate, acetate and $\mathrm{H}_{2}$. Acetate, propionate, isobutyrate, isovalerate and benzoate do not support growth of the co-culture. Fumarate, sulfate, thiosulfate, sulfur and nitrate cannot act as electron acceptors for butyrate oxidation. Crotonate is the only substrate tested that enables growth of the strain in pure culture, whilst yeast extract, tryptone, glucose, ribose, xylose, pyruvate and fumarate do not. Cellular fatty acids comprise mainly $\mathrm{C}_{14: 0}(27 \cdot 82 \%), \mathrm{C}_{15: 0}(19 \cdot 24 \%), \mathrm{C}_{14: 0}$ $3-\mathrm{OH}(10 \cdot 90 \%)$ and an unknown component of ECL $14 \cdot 503(21 \cdot 44 \%)$. Genomic DNA G $+\mathrm{C}$ content is $46 \cdot 6 \mathrm{~mol} \%$.

The type strain, GB8- $1^{\mathrm{T}} \quad\left(=\mathrm{CGMCC} \quad 1.5010^{\mathrm{T}}=\mathrm{DSM}\right.$ $\left.15682^{\mathrm{T}}\right)$, was isolated from the granular sludge of a UASB reactor treating beer wastewater in Beijing, China.

\section{Acknowledgements}

This research has been supported by the National Outstanding Youth Foundation (30025001) and the ' 863 Programme' from the Chinese Ministry of Sciences and Technology (2001AA227131).

\section{References}

Beaty, P. S. \& McInerney, M. J. (1987). Growth of Syntrophomonas wolfei in pure culture on crotonate. Arch Microbiol 147, 389-393.

Broda, D. M., Saul, D. J., Bell, R. G. \& Musgrave, D. R. (2000). Clostridium algidixylanolyticum sp. nov., a psychrotolerant, xylandegrading, spore-forming bacterium. Int J Syst Evol Microbiol 50, 623-631.

Hungate, R. E. (1969). A roll-tube method for the cultivation of strict anaerobes. Methods Microbiol 3B, 117-132.

Jackson, B. E., Bhupathiraju, V. K., Tanner, R. S., Woese, C. R. \& Mclnerney, M. J. (1999). Syntrophus aciditrophicus sp. nov., a new anaerobic bacterium that degrades fatty acids and benzoate in syntrophic association with hydrogen-using microorganisms. Arch Microbiol 171, 107-114.

Lorowitz, W. H., Zhao, H. \& Bryant, M. P. (1989). Syntrophomonas wolfei subsp. saponavida subsp. nov., a long-chain fatty-acid-degrading, 
anaerobic, syntrophic bacterium; Syntrophomonas wolfei subsp. wolfei subsp. nov.; and emended descriptions of the genus and species. Int J Syst Bacteriol 39, 122-126.

Marmur, J. (1961). A procedure for the isolation of deoxyribonucleic acid from microorganisms. J Mol Biol 3, 208-218.

Marmur, J. \& Doty, P. (1962). Determination of the base composition of deoxyribonucleic acid from its thermal denaturation temperature. J Mol Biol 5, 109-118.

Matthies, C., Springer, N., Ludwig, W. \& Schink, B. (2000). Pelospora glutarica gen. nov., sp. nov., a glutarate-fermenting, strictly anaerobic, spore-forming bacterium. Int J Syst Evol Microbiol 50, 645-648.

McInerney, M. J. (1992). The genus Syntrophomonas and other syntrophic anaerobes. In The Prokaryotes, a Handbook on the Biology of Bacteria: Ecophysiology, Isolation, Identification, Applications, 2nd edn, pp. 2048-2057. Edited by A. Balows, H. G. Trüper, M. Dworkin, W. Harder \& K. H. Schleifer. New York: Springer.

McInerney, M. J., Bryant, M. P. \& Pfennig, N. (1979). Anaerobic bacterium that degrades fatty acids in syntrophic association with methanogens. Arch Microbiol 122, 129-135.

McInerney, M. J., Bryant, M. P., Hespell, R. B. \& Costerton, J. W. (1981). Syntrophomonas wolfei gen. nov., sp. nov., an anaerobic, syntrophic, fatty acid-oxidizing bacterium. Appl Environ Microbiol 41, 1029-1039.

Reynolds, E. S. (1963). The use of lead citrate at high $\mathrm{pH}$ as an electron-opaque stain in electron microscopy. J Cell Biol 17, 208-212.

Rhuland, L. E., Work, E., Denman, R. F. \& Hoare, D. S. (1955). The behavior of the isomers of $\alpha, \varepsilon$-diaminopimelic acid on paper chromatograms. J Am Chem Soc 77, 4844-4846.

Roy, F., Samain, E., Dubourguier, H. C. \& Albagnac, G. (1986). Syntrophomonas sapovorans sp. nov., a new obligately proton reducing anaerobe oxidizing saturated and unsaturated long chain fatty acids. Arch Microbiol 145, 142-147.

Schink, B. (1997). Energetics of syntrophic cooperation in methanogenic degradation. Microbiol Mol Biol Rev 61, 262-280.

Sekiguchi, Y., Kamagata, Y., Nakamura, K., Ohashi, A. \& Harada, H. (2000). Syntrophothermus lipocalidus gen. nov., sp. nov., a novel thermophilic, syntrophic, fatty-acid-oxidizing anaerobe which utilizes isobutyrate. Int J Syst Evol Microbiol 50, 771-779.

Stieb, M. \& Schink, B. (1985). Anaerobic oxidation of fatty acids by Clostridium bryantii sp. nov., a sporeforming, obligately syntrophic bacterium. Arch Microbiol 140, 387-390.

Svetlitshnyi, V., Rainey, F. \& Wiegel, J. (1996). Thermosyntropha lipolytica gen. nov., sp. nov., a lipolytic, anaerobic, alkalitolerant, thermophilic bacterium utilizing short- and long-chain fatty acids in syntrophic coculture with a methanogenic archaeum. Int J Syst Bacteriol 46, 1131-1137.

Touzel, J. P. \& Albagnac, G. (1983). Isolation and characterization of Methanococcus mazei strain $\mathrm{MC}_{3}$. FEMS Microbiol Lett 16, 241-245.

Weisburg, W. G., Barns, S. M., Pelletier, D. A. \& Lane, D. J. (1991). $16 \mathrm{~S}$ ribosomal DNA amplification for phylogenetic study. J Bacteriol 173, 697-703.

Zhao, H., Yang, D., Woese, C. R. \& Bryant, M. P. (1990). Assignment of Clostridium bryantii to Syntrophospora bryantii gen. nov., comb. nov. on the basis of a 16S rRNA sequence analysis of its crotonategrown pure culture. Int J Syst Bacteriol 40, 40-44.

Zhao, H., Yang, D., Woese, C. R. \& Bryant, M. P. (1993). Assignment of fatty acid- $\beta$-oxidizing syntrophic bacteria to Syntrophomonadaceae fam. nov. on the basis of $16 \mathrm{~S}$ rRNA sequence analysis. Int J Syst Bacteriol 43, 278-286. 